\title{
Antioxidant and Angiotensin I-Converting Enzyme (ACE) Inhibitory Peptides Obtained from Alcalase Protein Hydrolysate Fractions of Hemp (Cannabis sativa L.) Bran
}

\author{
Seyedeh P. Samaei, ${ }^{\#}$ Serena Martini, ${ }^{\#}$ Davide Tagliazucchi, Andrea Gianotti, and Elena Babini*
}

Cite This: J. Agric. Food Chem. 2021, 69, 9220-9228

Read Online

ACCESS | Lill Metrics \& More | 回 Article Recommendations ｜ＳＳ Supporting Information

ABSTRACT: Proteins from hemp bran (HPB), a byproduct of the hemp seed food-processing chain, were chemically extracted, hydrolyzed by Alcalase, and separated by membrane ultrafiltration into four fractions ( $\mathrm{MW}<1,1-3,3-5$, and $>5 \mathrm{kDa}$ ). The antioxidant and antihypertensive properties of the initial extract and the fractions were evaluated by in vitro assays for their ability to scavenge radical species, bind with metal ions, reduce ferric ions, and inhibit angiotensin-converting enzyme (ACE) activity. Bioactive peptides were identified by high-resolution mass spectrometry and sequence comparison with BIOPEP and BioPep DB databases. The hydrolysate was strongly antioxidant and ACE-inhibiting; the most bioactive peptides were further concentrated by ultrafiltration. Of the 239 peptides identified, 47 (12 antioxidant and 35 ACE-inhibitory) exhibited structural features correlated with the specific bioactivity. These results highlight the promise of hydrolysate and size-based HPB fractions as natural functional ingredients for the food or pharmaceutical industry.

KEYWORDS: food byproduct, protein hydrolysates, antihypertensive peptides, antioxidant peptides, high-resolution mass spectrometry

\section{INTRODUCTION}

In the last few years, the recovery of proteins from agricultural and agro-food industry waste byproducts has garnered more attention, as improving the sustainability of the food chain has become more urgent. Aside from their nutritional properties, these proteins have additional value when transformed into bioactive hydrolysates, which may be beneficial for human health and have potential food and pharmaceutical applications. ${ }^{1}$ A classic approach for the preparation of these hydrolysates is the enzyme-catalyzed treatment of extracted proteins. The proteolytic reaction breaks down the primary sequence, producing mixtures of peptides with many positive health effects (antioxidant, antihypertensive, anti-inflammatory, anticancer, and antimicrobial, among others). ${ }^{2,3}$ The bioactivity of the crude hydrolysates can be enhanced by chemically or physically based downstream separation processes, which concentrate the bioactive peptides in mixtures of lower complexity. ${ }^{4-15}$ Purified peptides from these mixtures could provide even higher potency and greater specificity, but the costs associated with the large-scale purification of peptides have impeded the commercial exploitation of these products. ${ }^{16}$

To date, research in this field has primarily focused on peptides' antioxidant and blood-pressure-lowering effects. ${ }^{2,3}$ Peptides can act as antioxidants in many ways, including by inactivating reactive oxygen species, scavenging free radicals, chelating pro-oxidant transition metals, reducing hydroperoxides, and inhibiting linoleic acid oxidation. ${ }^{16}$ Peptides effective in preventing or treating hypertension mainly work by inhibiting angiotensin-converting enzyme (ACE) activity; $\mathrm{ACE}$ is an integral part of blood pressure regulation and electrolyte homeostasis. ${ }^{17}$

In this work, hemp (Cannabis sativa L.) bran (HPB), a byproduct of the hemp seed food-processing chain, was assessed as a substrate for the preparation of bioactive compounds possessing antioxidant and antihypertensive properties. Several research articles have been previously published on the bioactivity of protein hydrolysates, fractions, or isolated peptides from hemp seed and meal..$^{7-10,18-23}$ However, the specific HPB substrate, the coarser fraction of hemp meal (the part that remains after grinding and sieving the meal to obtain the flour, representing about $10 \%$ of the seed), has been only marginally studied to date. ${ }^{24,25}$ As reported by Pojić et al., ${ }^{24}$ HPB contains proteins whose amount (about $10-20 \%, w / w)$ varies depending on the sieving mesh size. Different biotransformation processes (enzymatic hydrolysis, microbial fermentation, and solid-state fermentation by the oyster mushroom Pleurotus ostreatus) have recently proved that HPB can yield products with antioxidant and antihypertensive properties. ${ }^{25}$ The antihypertensive activity was particularly impressive: the $\mathrm{IC}_{50}$ values for $\mathrm{ACE}$ inhibition of bioprocessed samples were similar to those in protein hydrolysates from the whole hemp seed. ${ }^{25}$ To identify the peptides responsible for the bioactivity detected in bioprocessed HPB, the byproduct was hydrolyzed by Alcalase and divided by membrane ultrafiltration into four fractions of different molecular weights

Received: March 13, 2021

Revised: July 17, 2021

Accepted: July 26, 2021

Published: August 6, 2021

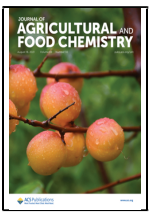


(MWs). The ability of protein-derived bioactive peptides to exert their activity is strictly dependent on their structure. To better understand the relationship between the peptides' structural features and their bioactivity, peptides in the lowMW fraction were identified by high-resolution mass spectrometry coupled with sequence screening in the BIOPEP and BioPep DB databases and subsequently analyzed. The results of this work may be useful for promoting the recovery of HPB byproducts to develop value-added products that can be used by the food/pharmaceutical industries.

\section{MATERIALS AND METHODS}

Raw Material and Chemicals. Milled hemp bran (HPB, the byproduct that remains when hemp seeds are mechanically pressed, ground, and sieved with a mesh size of $350 \mu \mathrm{m}$ ) was obtained from Hemp Positive World, Cesena, Italy. The analytical-grade reagents were made by Merck (Darmstadt, Germany). The precast gels, bovine serum albumin (BSA), MW marker for sodium dodecyl sulfatepolyacrylamide gel electrophoresis (SDS-PAGE), and mass spectrometry solvents were all obtained from Bio-Rad (Hercules, CA, USA).

Protein Extraction. The procedure described by Setti et al. ${ }^{25}$ was used to extract the protein from HPB. Briefly the procedure consists of mixing the HPB with distilled water in a ratio of 1:20 (w/v) and adjusting the $\mathrm{pH}$ to 10.0 (by adding $2 \mathrm{~N} \mathrm{NaOH}$ ). The mixture was stirred for an hour and then centrifuged $\left(8000 \mathrm{~g}, 30 \mathrm{~min}, 4^{\circ} \mathrm{C}\right)$. The supernatant was precipitated isoelectrically by adding $2 \mathrm{~N} \mathrm{HCl}$ to achieve a $\mathrm{pH}$ of 5.0. The mixture was centrifuged $(8000 \mathrm{~g}, 10 \mathrm{~min}, 4$ ${ }^{\circ} \mathrm{C}$ ), and the resulting protein pellet was suspended in deionized water and further homogenized. This suspension was then adjusted to $\mathrm{pH} 7$ using $2 \mathrm{~N} \mathrm{NaOH}$ and freeze-dried in a Heto Power Dry LL300 freeze dryer (Thermo Fisher Corp.). The yield of hemp bran protein extract (HPBPE) was calculated as the ratio $(\%, w / w)$ of the dry mass of HPBPE to the amount of the original raw material.

Enzymatic Hydrolysis. The HPBPE was first dissolved in deionized water $(12.5 \%, \mathrm{w} / \mathrm{v})$ and hydrolyzed with Alcalase $2 \%(\mathrm{v} /$ v) at $\mathrm{pH} 8$ for $2 \mathrm{~h}$ at $50{ }^{\circ} \mathrm{C}$, as previously reported for the same substrate. $^{25}$ The enzyme was inactivated, stopping the reaction, by heating the HPBPE to $85{ }^{\circ} \mathrm{C}$ for $15 \mathrm{~min}$. After cooling to room temperature, the solution was centrifuged $\left(14,000 \mathrm{~g}, 20 \mathrm{~min}, 4{ }^{\circ} \mathrm{C}\right)$. The supernatant, Alcalase hydrolysate, was immediately collected and stored at $-80{ }^{\circ} \mathrm{C}$. The enzymatic digestion was carried out in triplicate; the three samples were combined (hereafter referred to as Alc) for fractionation, SDS-PAGE analysis, and bioactivity assays. The yield of hydrolyzed protein was calculated as the ratio $(\%, w / w)$ of the dry mass of Alc to the dry mass of HPBPE.

Fractionation of Protein Hydrolysate by Membrane Ultrafiltration. The Alc sample was fractioned by membrane ultrafiltration on a $50 \mathrm{~mL}$ Amicon stirred cell (Millipore, USA). Three regenerated cellulose membranes (Millipore, USA) with cutoffs of 5, 3, and $1 \mathrm{kDa}$ were used in sequence, creating four fractions: F1 with $\mathrm{MW}>5 \mathrm{kDa}$, F2 with MW between 5 and $3 \mathrm{kDa}, \mathrm{F} 3$ with MW between 3 and 1 $\mathrm{kDa}$, and $\mathrm{F} 4$ with $\mathrm{MW}<1 \mathrm{kDa}$. The fractions were freeze-dried in a Heto Power Dry LL300 freeze dryer (Thermo Fisher Corp.) and then stored at $-20{ }^{\circ} \mathrm{C}$. Each fraction's yield was assessed as the ratio (\%, $\mathrm{w} / \mathrm{w}$ ) of the dry mass of the fraction to the dry mass of HPBPE.

Protein Pattern Analysis (Tricine SDS-PAGE). The protein pattern of each sample was analyzed on hand-cast $4 \%$ stacking, $10 \%$ separating, and $16 \%(\mathrm{w} / \mathrm{v})$ separating tricine SDS-PAGE with the Mini-PROTEAN equipment (Bio-Rad, Hercules, CA, USA). Bio-Rad also provided the Precision Plus Protein Standard, which was used to determine the MW of each sample.

Evaluation of Protein Content (Kjeldahl Assay). The Kjeldahl method was used to determine the protein content. Briefly, $1.0 \mathrm{~g}$ (d.w.) of the sample was mixed with $10 \mathrm{~mL}$ of a 95:5 (v/v) $\mathrm{H}_{2} \mathrm{SO}_{4}$ / $\mathrm{H}_{3} \mathrm{PO}_{4}$ solution and incubated at $420{ }^{\circ} \mathrm{C}$ for $180 \mathrm{~min}$. Distillation was performed by adding $32 \%(\mathrm{v} / \mathrm{v}) \mathrm{NaOH}$; the sample was then titrated using $0.1 \mathrm{~N} \mathrm{H}_{2} \mathrm{SO}_{4}$. Results were expressed in $\mathrm{g}$ proteins/100 $\mathrm{g}$ sample, applying the protein conversion factor $N=6.25$.
Evaluation of Degree of Hydrolysis (DH). The DH of HPBPE hydrolysates was described as the quantity of soluble protein in $10 \%$ $(\mathrm{w} / \mathrm{v})$ trichloroacetic acid (TCA) compared to the total protein content of the sample (in percent). ${ }^{26}$ A $5 \mathrm{~mL}$ aliquot of $2 \mathrm{~h}$ Alcalase digested sample was combined with $5 \mathrm{~mL}$ of $20 \%$ (w/v) TCA. After the mixture stood for $5 \mathrm{~min}$ at room temperature, it was centrifuged $\left(14,000 \mathrm{~g}, 10 \mathrm{~min}, 4{ }^{\circ} \mathrm{C}\right)$, and the supernatant was analyzed by the Kjeldahl assay to obtain the Alc 10\% TCA-soluble nitrogen. This value was used in the following equation to calculate the DH (\%):

$$
\mathrm{DH}(\%)=\operatorname{Alc} 10 \% \mathrm{TCA}-\text { soluble } N \cdot 100 / \text { total } N \text {, }
$$

where total $N$ is the total nitrogen content in undigested HPBPE (g) measured by the Kjeldahl assay.

Assays of Antioxidant Activity. Antioxidant activity was ascertained by the following assays: ABTS (2,20-azino-bis-3-ethylbenzothiazoline-6-sulfonic acid) and DPPH (1,1-diphenyl-2-picrylhydrazyl) radical scavenging activity (ARSA and DRSA, respectively), ferrous ion-chelating ability (FCA), and ferric-reducing antioxidant power (FRAP). Lyophilized samples were dissolved in water at $10 \%$ $(\mathrm{w} / \mathrm{v})$ concentration and centrifuged $(14,000 \mathrm{~g}, 10 \mathrm{~min})$; the supernatant was collected and adjusted to $\mathrm{pH} 7$. All analyses were performed in triplicate on a microplate scale (SPARK 10M, TECAN, Switzerland). The results were given as $\mathrm{IC}_{50}$ values ( $\mathrm{mg}$ of lyophilized sample/mL with $50 \%$ activity).

The ARSA was determined by following the procedure reported by Setti et al. ${ }^{25}$ The ABTS stock solution ( $7 \mathrm{mM}$ in $2.45 \mathrm{mM} \mathrm{K} \mathrm{S}_{2} \mathrm{O}_{8}$ ) was diluted using sodium acetate $(20 \mathrm{mM}, \mathrm{pH} 4.5)$ until an absorbance of $0.70 \pm 0.02$ at $734 \mathrm{~nm}$ was achieved. Then, $198 \mu \mathrm{L}$ of this solution mixed with $2 \mu \mathrm{L}$ of the sample was incubated in the dark at room temperature for $30 \mathrm{~min}$. The absorbance was measured at $734 \mathrm{~nm}$. A blank of distilled water was used (instead of the sample), and ascorbic acid (AA) served as a positive control.

The DRSA was also determined using the method of Setti et al. ${ }^{25} \mathrm{~A}$ $20 \mu \mathrm{L}$ aliquot of the sample was mixed with $180 \mu \mathrm{L}$ of $50 \mu \mathrm{M}$ DPPH solution in methanol. After the mixture was incubated in the dark at room temperature for $30 \mathrm{~min}$, the absorbance was measured at 517 $\mathrm{nm}$. The blank and the positive control were the same as those for determining the ARSA.

The ferrous ion-chelating activity was also measured according to the method of Setti et al., ${ }^{25}$ with slight modifications. The sample (25 $\mu \mathrm{L}$ ) was mixed with $100 \mu \mathrm{L}$ of $300 \mu \mathrm{M}$ ferrozine and $100 \mu \mathrm{L}$ of 50 $\mu \mathrm{M} \mathrm{FeSO}{ }_{4}$ and incubated at room temperature for $10 \mathrm{~min}$. The absorbance was then measured at $562 \mathrm{~nm}$. The positive control consisted of ethylenediaminetetraacetic acid (EDTA).

The FRAP was measured using a method based on the fact that the $\mathrm{Fe}^{3+}$-TPTZ (2,4,6-tripyridyl-s-triazine) complex reduces to $\mathrm{Fe}^{2+}$ TPTZ at a low $\mathrm{pH}$ when antioxidants are present. ${ }^{27}$ The FRAP reagent was prepared by mixing $1 \mathrm{~mL}$ of a $10 \mathrm{mM}$ TPTZ solution in $40 \mathrm{mM} \mathrm{HCl}, 1 \mathrm{~mL}$ of $20 \mathrm{mM} \mathrm{FeCl}_{3}$, and $10 \mathrm{~mL}$ of $300 \mathrm{mM}$ acetate buffer with $\mathrm{pH}$ 3.6. Aliquots of the sample $(10 \mu \mathrm{L})$ were blended with $300 \mu \mathrm{L}$ of the FRAP reagent; after incubation at room temperature for $10 \mathrm{~min}$, the absorbance of the mixture at $593 \mathrm{~nm}$ was measured. AA was used as the positive control.

Assay of the ACE-Inhibitory Activity. The ACE-inhibitory activity was measured using the method of Sentandreu and Toldra. ${ }^{28}$ Aliquots of the sample $(50 \mu \mathrm{L})$ were mixed with the ACE solution $(50 \mu \mathrm{L}, 15 \mathrm{mU} / \mathrm{mL})$ and preincubated at $37{ }^{\circ} \mathrm{C}$ for $10 \mathrm{~min}$. The addition of $200 \mu \mathrm{L}$ of preheated $\left(37^{\circ} \mathrm{C}\right) 0.45 \mathrm{mM} \mathrm{o}$-aminobenzoylglycyl-P-nitro-L-phenylalanyl-L-proline (Abz-Gly-Phe $\left(\mathrm{NO}_{2}\right)$ Pro), dissolved in $150 \mathrm{mM}$ Tris buffer ( $\mathrm{pH} 8.3$ ) containing 1.125 $\mathrm{M} \mathrm{NaCl}$, started the reaction. The mixture was incubated at $37^{\circ} \mathrm{C}$ for $30 \mathrm{~min}$. The fluorescence generated by the release of the $o$ aminobenzoylglycine (Abz-Gly) group was measured using excitation and emission wavelengths of 355 and $405 \mathrm{~nm}$, respectively, using a fluorometer microplate reader (SPARK 10M, TECAN, Switzerland). The standard curve was obtained by using different concentrations of Abz-Gly (from 5 to $30 \mu \mathrm{M}$ ). The $\mathrm{IC}_{50}$ values $(\mathrm{mg} / \mathrm{L}$ ) were determined by nonlinear regression analysis. The spectrophotometric data were fit to the log (inhibitor) vs the response model, which was 


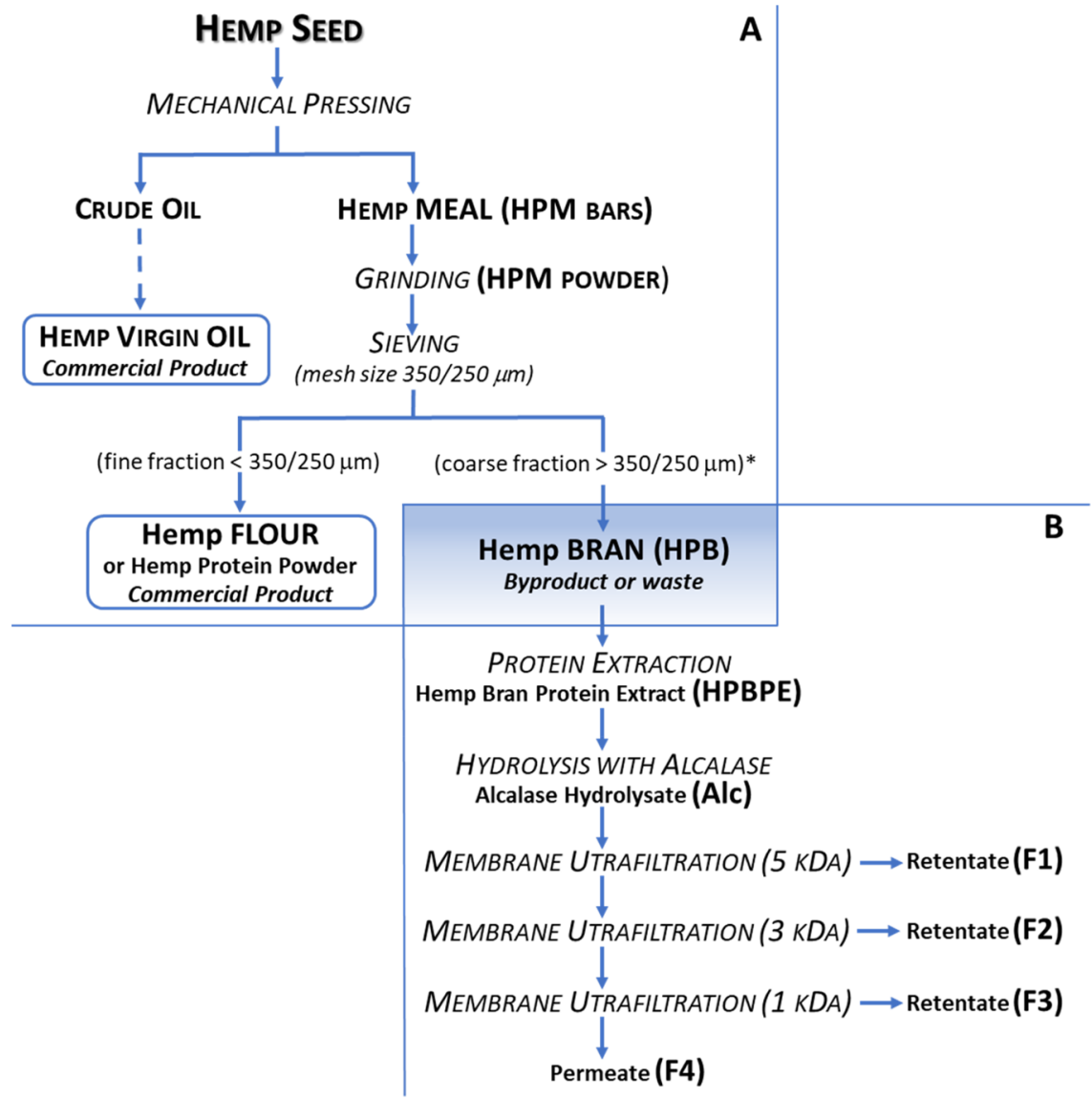

Figure 1. Simplified flow diagram of the (A) industrial processing of hemp seed for the production of the two commercial products, virgin oil and flour, and (B) experimental processing of the hemp bran (HPB) byproduct to produce the samples analyzed in the present work. Abbreviations in parentheses: Alc, HPBPE hydrolyzed by Alcalase; F1, Alc peptide fraction $>5 \mathrm{kDa}$; F2, Alc peptide fraction from 3 to $5 \mathrm{kDa}$; F3, Alc peptide fraction from 1 to $3 \mathrm{kDa}$; F4, Alc peptide fraction <1 kDa; HPBPE, HPB protein extract; HPM, hemp meal. *The HPB used in the present work was produced by the company using a $350 \mu \mathrm{m}$ mesh size.

generated by GraphPad Prism 8.0 (GraphPad Software, San Diego, CA, USA).

Peptide Identification Using High-Resolution Mass Spectrometry. The peptidomic profile of fraction F4 $(<1 \mathrm{kDa})$ was analyzed by UHPLC (UHPLC Ultimate 3000 , Thermo Scientific, San Jose, CA, USA) coupled with high-resolution mass spectrometry ( $Q$ Exactive Hybrid Quadrupole-Orbitrap Mass Spectrometer, Thermo Scientific, San Jose, CA, USA). A Zorbax C18 column was used for the chromatographic separation (Zorbax SB-C18 Reversed-phase, 2.1 $\times 50 \mathrm{~mm}, 1.8 \mu \mathrm{m}$ particle size, Agilent Technologies, Santa Clara, CA, USA). Further information about the mobile phases, the elution gradient, and the mass spectrometry parameters is provided by Martini et al. ${ }^{29}$ De novo peptide sequencing was carried out with the Pepnovo software (http://proteomics.ucsd.edu/ProteoSAFe/) with the following parameters: fragment mass tolerance, $\pm 0.12 \mathrm{Da}$; peptide mass tolerance, $\pm 5 \mathrm{ppm}$; enzyme, none; and oxidation $(\mathrm{M})$ and phosphorylation (ST) as variable modifications. Each identified peptide was confirmed by manual inspection of the MS and $\mathrm{MS}^{2}$ spectra. Two different databases (BIOPEP and BioPep DB) were used for the identification of peptides with previously reported biological activity. ${ }^{30,31}$

Statistical Analysis. Each analysis was performed in triplicate, and results are reported as mean value \pm SD. Statistical testing was performed using the SPSS software (SPSS16, Inc., USA). Determining whether differences among means were significant was accomplished by the use of a one-way analysis of variance (ANOVA) with Tukey test and a significant level of $p<0.05$.

\section{RESULTS AND DISCUSSION}

Experimental samples were obtained from a byproduct of the hemp seed food-processing chain (Figure 1). The seeds are processed by the food industry to provide two main commercial products: virgin oil and flour (the latter also known as hemp protein powder) (Figure 1A). The first step of the process is the mechanical pressing of the seeds, which yields crude oil and small cylindrical bars of hemp meal (HPM). The oil is subsequently refined into virgin oil. The bars are ground into powder and sieved, which separates the flour from the larger particles (larger than $250-350 \mu \mathrm{m}$, depending on the degree of flour refining). The coarser fraction (hemp bran, HPB), representing about $10 \%$ of the seed, is normally used for animal feed or even discarded. This fraction is relatively high in proteins, although the percentage depends on the seed varieties and extraction procedures. Pojic et al. $^{24}$ estimated that HPB preparations including particles larger than 250 and $350 \mu \mathrm{m}$ contained approximately 20 and $11 \%(\mathrm{w} / \mathrm{w})$ protein, respectively. In the present work, HPB > $350 \mu \mathrm{m}$ was used; the protein content, as previously reported by the authors, was about $20 \%(\mathrm{w} / \mathrm{w}){ }^{25}$ The procedure to convert HPB into added-value hydrolysates is reported in Figure 1B. The first two steps (chemical extraction and hydrolysis with Alcalase) reproduced a process previously used by the authors to generate, from the HPB matrix, hydrolysates with improved bioactive properties. ${ }^{25}$ This procedure was 
further extended in the present work by adding sequential membrane ultrafiltration steps to separate the hydrolysates into four fractions: $\mathrm{MW}>5 \mathrm{kDa}(\mathrm{F} 1), 5-3 \mathrm{kDa}$ (F2), 3-1 kDa (F3), and $<1 \mathrm{kDa}(\mathrm{F} 4)$. Some papers reported the increased bioactivity of HPM protein hydrolysates after peptide separation in different fractions, according to their MW or hydrophobicity. ${ }^{8-10}$ Many other examples exist in the literature for the fractionation of protein hydrolysates from other matrices. ${ }^{12,14}$ The addition of a purification step (such as ultrafiltration or chromatographic separation) raises the processing costs; however, on an industrial scale, the added cost may be justified by the greater commercial value of the product due to the increased bioactivity. Further advantages in the fractionation of hydrolysates could derive from the increased resistance to physiological digestion and the higher bioavailability of low MW peptides with respect to mixtures of more complex MW distribution.

Protein Profile, DH and Yield of Hydrolysate, and Ultrafiltration Fractions. The efficiency of the Alcalase digestion of HPBPE and of hydrolysate fractionation by membrane ultrafiltration was followed by checking the protein profile on tricine SDS-PAGE (Figure 2). The initial protein

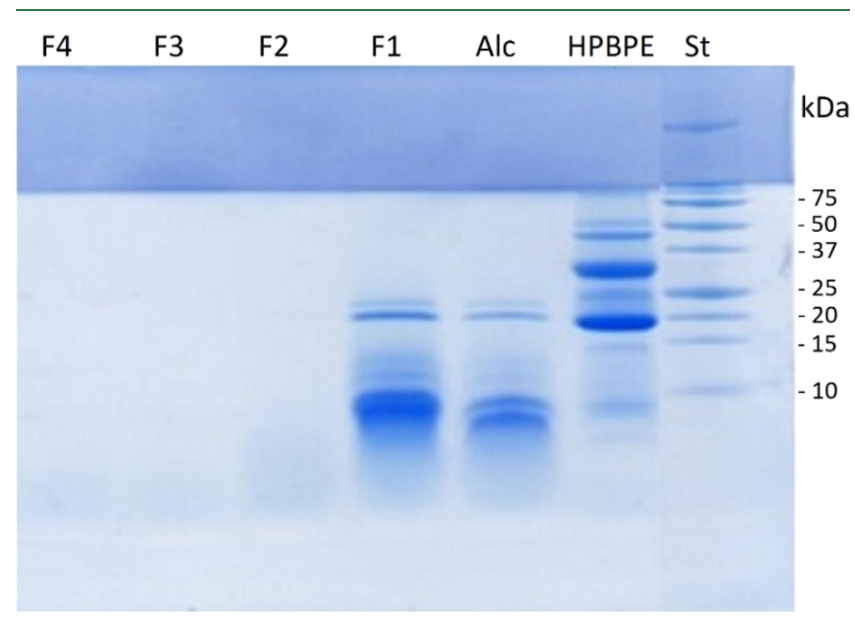

Figure 2. Tricine SDS-PAGE of the hemp bran protein extract (HPBPE); its hydrolysate with Alcalase (Alc); and peptide fractions F1 (>5 kDa), F2 (3-5 kDa), F3 (1-3 kDa), and F4 (<1 KDa). St: MW marker.

extract (HPBPE) showed bands with MW up to $75 \mathrm{kDa}$. After hydrolysis, bands with MW higher than $20 \mathrm{kDa}$ disappeared, leaving smaller bands, partially unresolved, that confirmed the efficacy of the proteolytic reaction. Fractionation was able to separate peptides with $\mathrm{MW}>5 \mathrm{kDa}$ in the $\mathrm{F} 1$ sample, which formed clearly visible smeared bands on SDS-PAGE, the most intense with a MW close to $10 \mathrm{kDa}$. These bands totally disappeared in F2 to F4 samples, which contained peptides with progressively lower MW, as expected for the membrane cutoff of ultrafiltration steps. The $\mathrm{DH}$ (indicating the percent of bonds available for proteolytic hydrolysis that were actually cleaved) is a standard parameter for monitoring the level of proteolysis. The DH of HPBPE by Alcalase was 27.46\% (Table 1 ), which falls within the range of previously reported single enzymatic treatments of HPM protein extracts (reported as 19.7 to $47.5 \%^{22}$ and as $39.1 \%^{9}$ ). The yield of the HPBPE hydrolysate and of each fraction obtained by membrane ultrafiltration is also reported in Table 1. This parameter is another important yardstick of the efficiency of enzymatic
Table 1. Percent Yield of Hemp Bran Protein Extract (HPBPE); Its Hydrolysate with Alcalase (Alc); and the Alc Peptide Fractions F1 ( $>5 \mathrm{kDa})$, F2 $(3-5 \mathrm{kDa})$, F3 (1-3 $\mathrm{kDa})$, and $\mathrm{F} 4(<1 \mathrm{kDa})^{a}$

\begin{tabular}{lll} 
sample & \multicolumn{1}{c}{ yield $(\%)$} & \multicolumn{1}{c}{ DH (\%) } \\
HPBPE & $7.05 \pm 0.57$ & NA \\
Alc & $70.02 \pm 1.79$ & $27.46 \pm 0.41$ \\
F1 & 21.13 & NA \\
F2 & 5.26 & NA \\
F3 & 4.84 & NA \\
F4 & 35.83 & NA
\end{tabular}

${ }^{a}$ The degree of hydrolysis (DH, \%) was measured for the HPBPE hydrolysate with Alcalase (Alc). NA means not applicable.

hydrolysis (a higher yield of hydrolysate/peptide fractions indicates an increase in protein breakdown); it is also relevant for determining the products' potential for commercial exploitation in the food industry (higher yield potentially meaning higher economic viability). The enzymatic hydrolysis of HPBPE with Alcalase caused $70 \%$ of the peptide yield, again in the range of previous reports for HPM hydrolysates (reported as 16 to $43 \%{ }^{22}$ and as $65.7 \%{ }^{9}$ ). The separation of the protein hydrolysate (Alc) by membrane ultrafiltration indicated that the lowest MW fraction (F4) was present in a higher proportion (35.83\%), followed by F1 (21.13\%), when compared to fractions F2 and F3 (5.26 and 4.84\%, respectively). A similar trend was obtained for HPM protein extract ultrafiltration fractions by Girgih et al. ${ }^{9}$

Antioxidant Properties. The antioxidant properties of HPBPE, Alc, and the fractions F1 to F4 were evaluated by four different assays: ARSA, DRSA, FCA, and FRAP. The ARSA and DRSA measure the ability to scavenge stable radical species (ABTS and DPPH, respectively). The FCA assay evaluates the total antioxidant capacity indirectly, measuring the $\mathrm{Fe}^{2+}$ chelation by ferrozine to form a stable complex. The FRAP assay evaluates the ability of antioxidants to directly reduce $\mathrm{Fe}^{3+}$ as an electron-donating activity indicator. The results of all assays are reported as $\mathrm{IC}_{50}$ values; the lowest value indicates the highest activity (Figure 3 ).

The results of the ARSA, DRSA, and FRAP assays had similar trends (Figure 3A,B,D). Enzymatic hydrolysis with Alcalase strongly increased the antioxidant activity, compared to HPBPE, as exerted by the three mechanisms. Indeed, the $\mathrm{IC}_{50}$ values decreased with respect to those of the undigested sample, of about 85,69 , and $76 \%$, respectively. The fourth assay, FCA, showed a different trend, as hydrolysis with Alcalase did not have a positive effect on $\mathrm{Fe}^{2+}$ chelation with respect to HPBPE (Figure $2 \mathrm{C}$ ). The $\mathrm{IC}_{50}$ values of the two samples were indeed comparable $(0.50$ and $0.53 \mathrm{mg} / \mathrm{mL}$ for undigested and digested samples, respectively). Similar results for ARSA and FRAP assays were previously reported for the HPB Alcalase hydrolysate. ${ }^{27}$ Furthermore, enzymatic hydrolysis (by Alcalase or other enzymes) increased the antioxidant properties of proteins extracted from HPM.,8,10,18-20,32 The hydrolysis of protein, as already stated for many other substrates, allows the release of specific protein fragments that, although inactive within the parent proteins, become active when free in the solution. The fractionation of the Alc hydrolysate by membrane ultrafiltration increased the antioxidant activities of all $\mathrm{F} 1$ samples that had $\mathrm{IC}_{50}$ values $(0.19$, $0.18,0.22$, and $0.21 \mathrm{mg} / \mathrm{mL}$ for ARSA, DRSA, FCA, and FRAP, respectively) significantly lower than those of the 
A ABTS radical scavenging activity

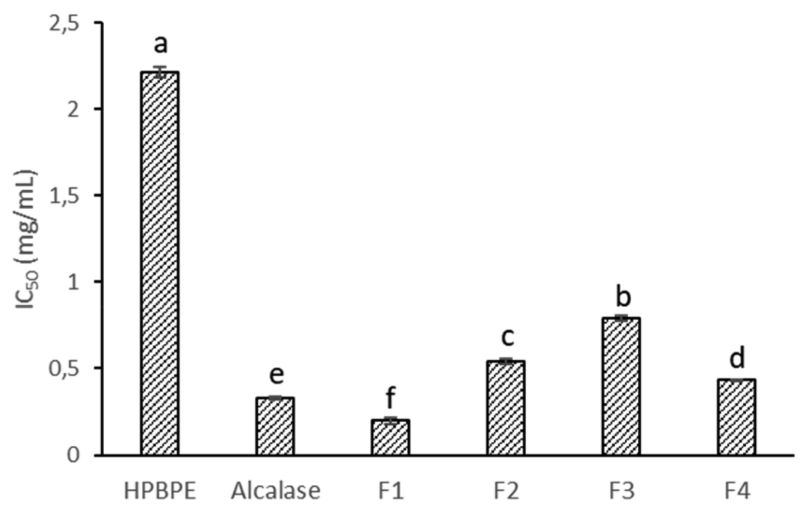

C

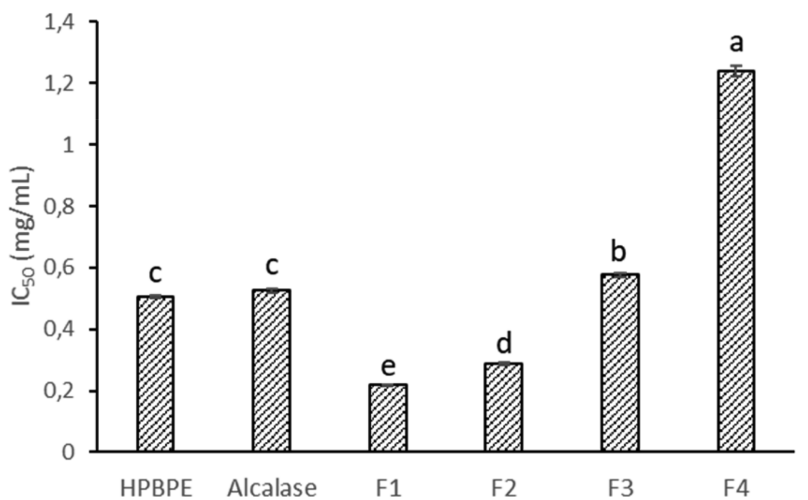

B

DPPH radical scavenging activity

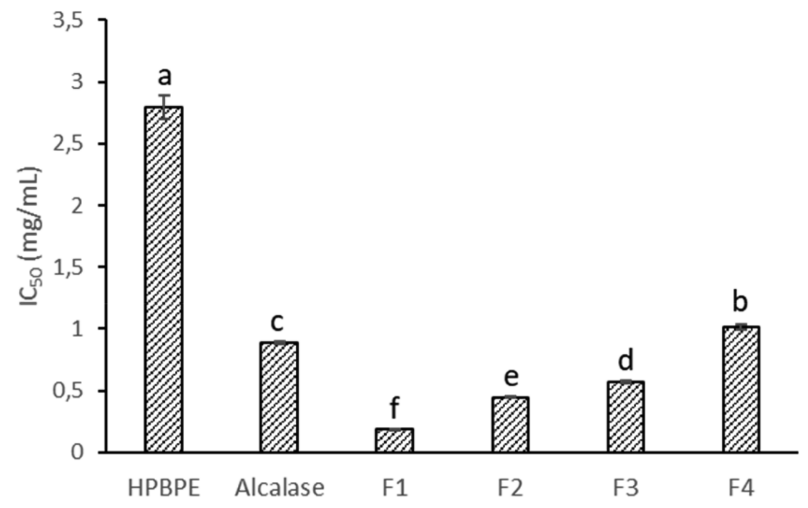

D

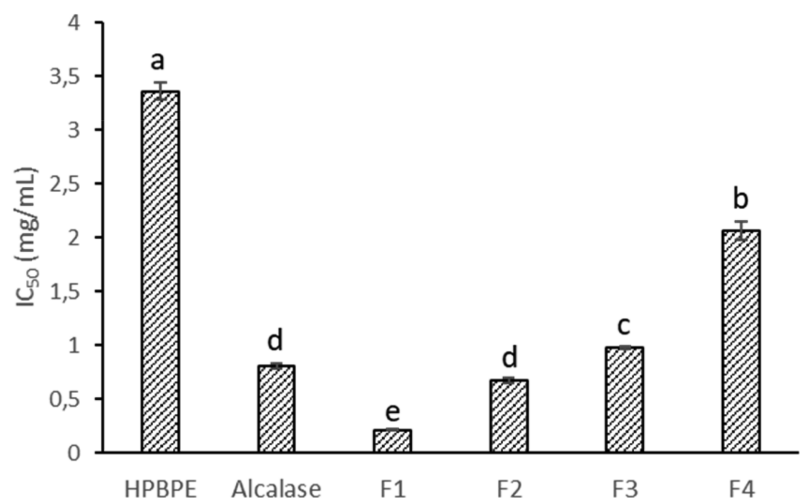

Figure 3. Antioxidant activity, expressed as $\mathrm{IC}_{50}$ values $(\mathrm{mg} / \mathrm{mL})$, of the hemp bran protein extract (HPBPE); its hydrolysate with Alcalase (Alc); and peptide fractions F1 (>5 kDa), F2 (3-5 kDa), F3 (1-3 kDa), and F4 (<1 KDa). (A) ABTS radical scavenging activity; (B) DPPH radical scavenging activity; (C) ferrous ion-chelating activity; and (D) ferric-reducing antioxidant power. Means followed by the same letter did not differ significantly (Tukey test, $p>0.05$ ).

unfractionated sample $(0.33,0.88,0.53$, and $0.81 \mathrm{mg} / \mathrm{mL}$ for ARSA, DRSA, FCA, and FRAP, respectively). The subsequent fractions, containing peptides with decreasing sizes, displayed a lower antioxidant activity than F1. Fractions F2, F3, and F4 had progressively increasing ARSA, DRSA, FCA, and FRAP $\mathrm{IC}_{50}$ values (with the exception of the ARSA value of sample F4, which was lower than that of the F3 and F2 samples). No data are available in the literature for peptide fractions from HPB protein extracts. The ultrafiltration fractions from HPM had antioxidant activity values that were dependent on the MW. ${ }^{8}$ An opposite trend was observed for HPB fractions for DRSA (smaller fractions showing higher potency), but the trend was similar for FCA and FRAP. Tang et al. ${ }^{7}$ demonstrated that increasing the time of HPM protein extract hydrolysis by different enzymes from 2 to $4 \mathrm{~h}$ (thus increasing the percentage of smaller peptides in solution) led in some cases to decreased DRSA, FCA, and FRAP values. Das ${ }^{20}$ also reported an inverse correlation between the degree of hydrolysis and the radical scavenging activity for the HPM protein extract hydrolyzed with different enzymes. Other examples of increasing antioxidant activity in higher MW fractions of protein hydrolysates come from other substrates. He et al. ${ }^{11}$ observed that high-MW $(5-10 \mathrm{kDa})$ fractions of the rapeseed protein hydrolysate exhibited the strongest chelating capacity. High-MW fractions of the pigeon pea protein hydrolyzed by pancreatin showed the highest DRSA and FRAP values. ${ }^{13} \mathrm{~A}$ decrease in DRSA activity with a decrease in the peptide sizes was observed for the yellow stripe trevally protein hydrolysate prepared using Alcalase. ${ }^{6}$

During hydrolysis, a mixture of small peptides and free amino acids is formed. Their antioxidative potential depends on the size of the generated peptides and the nature and sequence of their amino acid residues. In these mixtures, lowMW peptides are generally the most active for specific factors (easier steric interaction with the substrate, higher hydrophilicity and solubility, exposure of hydrophobic side chains, etc.) and their combination. The decrease of antioxidant activity with decreasing MW, as observed for F2 to F4 samples, could be related to the soluble peptide aggregates that form in the hydrolysates, hiding hydrophobic amino acid side chains and reducing reactive peptides. Alternatively, the decrease could be due to the formation of free amino acid residues (which exhibit lower antioxidant properties than amino acid sequences). Although the molecular basis of our findings is not yet known with certainty, the results of the antioxidant activity assays are promising. They confirmed the evidence of a preliminary work indicating that proteins extracted from this coarsest part of HPM (and not just from the entire HPM, as already established by other authors) have antioxidant properties, which can be significantly increased by Alcalase digestion. ${ }^{25}$ Besides, the addition of a purification step by membrane ultrafiltration with a cutoff of $5 \mathrm{kDa}$ (to isolate peptides with $\mathrm{MW}$ higher than $5 \mathrm{kDa}$ ) can further increase this activity because the combined effects of several properties, 
including peptides' ability to scavenge free radicals, act as chelating agents of metal ions, and donate hydrogen.

ACE-Inhibitory Activity. ACE catalyzes two important reactions that are responsible for constricting blood vessels, which in turn leads to elevated blood pressures. ${ }^{9}$ An in vitro ACE-inhibitory activity assay was used to screen the antihypertensive potential of HPBPE, Alc, and the fractions F1 to F4. Results are expressed as $\mathrm{IC}_{50}$ values $(\mathrm{mg} / \mathrm{L})$, indicating the concentration of the sample able to induce a $50 \%$ inhibition of the enzyme (Table 2). The hydrolysis of

Table 2. ACE-Inhibitory Activity of the Hemp Bran Protein Extract (HPBPE); Its Hydrolysate with Alcalase (Alc); and Alc Peptide Fractions F1 (>5 kDa), F2 (3-5 kDa), F3 (1-3 $\mathrm{kDa}$ ), and F4 (<1 kDa) (Means Followed by the Same Letter Did Not Differ Significantly (Tukey Test, $P>0.05)$ )

$\begin{array}{lc}\text { sample } & \text { ACE-inhibitory activity }\left(\mathrm{IC}_{50} \mathrm{mg} / \mathrm{L}\right)^{a} \\ \text { HPBPE } & 2798 \pm 0.121^{\mathrm{a}} \\ \text { Alc } & 83 \pm 0.034^{\mathrm{bB}} \\ \text { F1 } & 108 \pm 0.001^{\mathrm{bA}} \\ \text { F2 } & 83 \pm 0.004^{\mathrm{bB}} \\ \text { F3 } & 72 \pm 0.002^{\mathrm{bC}} \\ \text { F4 } & 72 \pm 0.001^{\mathrm{bC}}\end{array}$

${ }^{a}$ Statistical analysis was performed considering the samples all together and without HPBPE (lowercase and uppercase letters, respectively).

HPBPE by Alcalase had a strong positive effect on the ACEinhibitory activity as evidenced by an $\mathrm{IC}_{50}$ value of $80 \mathrm{mg} / \mathrm{L}$. Accordingly, these findings reveal that ACE-inhibitory peptides were released from HPB proteins during enzymatic hydrolysis. The $\mathrm{IC}_{50}$ value of the Alc sample was in the range of previous results obtained for HPB proteins hydrolyzed by Alcalase (176 $\mathrm{mg} / \mathrm{L}^{25}$ ) and for HPM proteins hydrolyzed by different enzymes $\left(16-228 \mathrm{mg} / \mathrm{L}^{21}\right)$. Similar $\mathrm{IC}_{50}$ values were observed for protein hydrolysates from other substrates $(140 \mathrm{mg} / \mathrm{L}$ for green soybean Alcalase hydrolysate ${ }^{33}$ and 224 and $226 \mathrm{mg} / \mathrm{L}$ for soybean and lupin pepsin digests, respectively ${ }^{34}$ ). Fractionation based on peptide MW was not as efficient as enzymatic hydrolysis to increase the inhibitory activity of the Alc sample. The ACE-inhibitory activity of ultrafiltered samples F3 and F4 was slightly increased with respect to the Alc sample ( $72 \mathrm{mg} / \mathrm{L}$, both), but the F1 and F2 fractions had higher or equal values (108 and $83 \mathrm{mg} / \mathrm{L}$, respectively). Membrane ultrafiltration of the HPM protein hydrolysate, reproducing the effects of gastrointestinal digestion, produced peptide fractions that were less inhibitory toward ACE than the original hydrolysate. The $\mathrm{IC}_{50}$ values were higher in the lowMW fractions (1050 and $1170 \mathrm{mg} / \mathrm{L}$ for $<1$ and $1-3 \mathrm{kDa}$, respectively) than the unfractionated sample $(670 \mathrm{mg} / \mathrm{L}) .{ }^{9}$ Conversely, reports on cod frame protein hydrolysate, ${ }^{5}$ shrimp, ${ }^{4}$ and sesame protein ${ }^{15}$ indicate that the ACE-inhibitory activity increases as the MW of peptide fractions (produced by ultrafiltration) decreases, as observed in the present study. This variability can be explained by the fact that size is not the only parameter affecting the peptides' ACE-inhibitory activity; the activity is also dependent on the presence of hydrophobic residues (aromatic or branched-chain) and on their position in the amino acidic sequence. ${ }^{17,35}$ In addition, in complex mixtures, the synergistic effect of different peptides can also be a factor, increasing the ACE-inhibitory potency of protein hydrolysates. ${ }^{9}$ Independent of the mode of ACE inhibition, the
$\mathrm{IC}_{50}$ values of the HPB hydrolysate and of the single fractions appear to be significant. They are comparable with values measured for other-sources protein hydrolysates, as previously reported, but also for pure peptides isolated from HPM hydrolysates $^{19}$ and reference antihypertensive peptides. ${ }^{28}$ These data suggest that both the hydrolysate and the single fractions can be considered as a valuable source of ACEinhibitory peptides, with the promise of application in the formulation of functional foods or dietary supplements that could prevent or treat hypertension.

Peptidomic Profile of Alcalase Hydrolysate Fraction F4 (<1 kDa). With the aim to identify alleged bioactive peptides, fraction F4 was subjected to high-resolution mass spectrometry analysis. The F4 fraction was selected for peptidomic investigation for its high biological potential (ACE-inhibitory and antioxidant activities) and for the presence of short peptide sequences, which are actually less susceptible to the action of gastrointestinal and brush-border proteases and, thus, potentially bioavailable. ${ }^{36}$ The full list of identified peptides as well as the mass spectrometry data is provided in Table S1. A total of 239 peptides having 2 to 9 amino acid residues and 4 free amino acids were detected in fraction F4. Among the identified peptides, 39 were dipeptides, 78 were tripeptides, 37 were tetrapeptides, and 85 contained 5 or more residues.

Some of the identified peptides have already been characterized as antioxidant or ACE-inhibitory peptides. Table 3 bears the identified peptides and amino acids formerly

Table 3. Peptides and Amino Acids with Previously Described Antioxidant Properties Identified in Fraction F4 $(<1 \mathrm{kDa})$

\begin{tabular}{|c|c|}
\hline sequence & activity \\
\hline LLY & $\begin{array}{l}\text { ABTS radical scavenging } \\
\text { peroxyl radical scavenging }\end{array}$ \\
\hline LLR & $\begin{array}{l}\text { ABTS radical scavenging } \\
\text { inhibition of lipid peroxidation }\end{array}$ \\
\hline IR & peroxyl radical scavenging \\
\hline TY & $\begin{array}{l}\text { ABTS radical scavenging } \\
\text { inhibition of lipid peroxidation } \\
\text { metal chelating ability }\end{array}$ \\
\hline VY & $\begin{array}{l}\text { ABTS radical scavenging } \\
\text { inhibition of lipid peroxidation }\end{array}$ \\
\hline LH & inhibition of lipid peroxidation \\
\hline EL & $\begin{array}{l}\text { DPPH radical scavenging } \\
\text { hydroxyl radical scavenging } \\
\text { superoxide anion scavenging activity }\end{array}$ \\
\hline $\mathrm{LK}$ & peroxyl radical scavenging \\
\hline AY & inhibition of lipid peroxidation \\
\hline $\mathrm{H}$ & $\begin{array}{l}\text { hydroxyl radical scavenging } \\
\text { inhibition of lipid peroxidation }\end{array}$ \\
\hline $\mathrm{R}$ & $\begin{array}{l}\text { hydroxyl radical scavenging } \\
\text { inhibition of lipid peroxidation }\end{array}$ \\
\hline $\mathrm{F}$ & $\begin{array}{l}\text { hydroxyl radical scavenging } \\
\text { inhibition of lipid peroxidation }\end{array}$ \\
\hline
\end{tabular}

described as antioxidant compounds. The C-terminal bulky Yresidue recorded in three dipeptides (AY, VY, and TY) and one tripeptide (LLY) is pivotal in determining the antioxidant activity of these peptides. The tripeptide LLY has already proven to be a strong antioxidant peptide both in vitro in cell culture and in vivo in mice under oxidative stress conditions. ${ }^{37}$ 
Previously, it was demonstrated that the occurrence of an antioxidant amino acid ( $\mathrm{Y}$ or $\mathrm{W}$ ) at the $\mathrm{C}$-terminus is of paramount importance for the ABTS and hydroxyl radical scavenging activities of bioactive peptides. ${ }^{38}$ Several di- and tripeptides containing $\mathrm{Y}$ at the $\mathrm{C}$-terminus were found in the fraction F4 (Table S1), which can contribute to the antioxidant properties of this fraction.

A total of 35 peptides previously described as ACEinhibitors were identified in fraction $\mathrm{F} 4$ and reported in Table 4. The tripeptides IVY and LIY, formerly isolated from

Table 4. Peptides with Previously Described AngiotensinConverting Enzyme (ACE)-Inhibitory Activity Identified in Fraction F4 $(<1 \mathrm{kDa})^{a}$

\begin{tabular}{|c|c|}
\hline sequence & $\mathrm{IC}_{50}{ }^{b}$ \\
\hline IVY & $0.5 \mu \mathrm{mol} / \mathrm{L}$ \\
\hline LIY & $0.8 \mu \mathrm{mol} / \mathrm{L}$ \\
\hline IIY & $1.1 \mu \mathrm{mol} / \mathrm{L}$ \\
\hline $\mathrm{EY}$ & $2.7 \mu \mathrm{mol} / \mathrm{L}$ \\
\hline $\mathrm{AI}$ & $3.4 \mu \mathrm{mol} / \mathrm{L}$ \\
\hline LVY & $5.8 \mu \mathrm{mol} / \mathrm{L}$ \\
\hline VY & $7.1 \mu \mathrm{mol} / \mathrm{L}$ \\
\hline VK & $13 \mu \mathrm{mol} / \mathrm{L}$ \\
\hline LVQ & $14 \mu \mathrm{mol} / \mathrm{L}$ \\
\hline AY & $19 \mu \mathrm{mol} / \mathrm{L}$ \\
\hline LGI & $29 \mu \mathrm{mol} / \mathrm{L}$ \\
\hline NY & $32 \mu \mathrm{mol} / \mathrm{L}$ \\
\hline IKY & $34 \mu \mathrm{mol} / \mathrm{L}$ \\
\hline VVF & $35 \mu \mathrm{mol} / \mathrm{L}$ \\
\hline ITF & $49 \mu \mathrm{mol} / \mathrm{L}$ \\
\hline $\mathrm{FQ}$ & $51 \mu \mathrm{mol} / \mathrm{L}$ \\
\hline LLP & $57 \mu \mathrm{mol} / \mathrm{L}$ \\
\hline SY & $66 \mu \mathrm{mol} / \mathrm{L}$ \\
\hline LLF & $80 \mu \mathrm{mol} / \mathrm{L}$ \\
\hline IVQ & $95 \mu \mathrm{mol} / \mathrm{L}$ \\
\hline LEE & $100 \mu \mathrm{mol} / \mathrm{L}$ \\
\hline SF & $130 \mu \mathrm{mol} / \mathrm{L}$ \\
\hline IA & $153 \mu \mathrm{mol} / \mathrm{L}$ \\
\hline LR & $158 \mu \mathrm{mol} / \mathrm{L}$ \\
\hline GY & $210 \mu \mathrm{mol} / \mathrm{L}$ \\
\hline ILP & $270 \mu \mathrm{mol} / \mathrm{L}$ \\
\hline LA & $310 \mu \mathrm{mol} / \mathrm{L}$ \\
\hline LTF & $330 \mu \mathrm{mol} / \mathrm{L}$ \\
\hline IR & $695 \mu \mathrm{mol} / \mathrm{L}$ \\
\hline FR & $920 \mu \mathrm{mol} / \mathrm{L}$ \\
\hline GI & $1200 \mu \mathrm{mol} / \mathrm{L}$ \\
\hline GL & $2500 \mu \mathrm{mol} / \mathrm{L}$ \\
\hline IE & n. a. ${ }^{c}$ \\
\hline EI & n. a. \\
\hline LQ & n. a. \\
\hline
\end{tabular}

${ }^{a}$ Peptides are listed based on their inhibitory potency. ${ }^{b} \mathrm{IC}_{50}$ is defined as the concentration of peptides required to inhibit $50 \%$ of the enzymatic activity. The values are from the BIOPEP and MBPDB

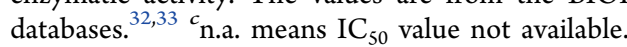

wheat germ hydrolysate and human plasma, respectively, showed $\mathrm{IC}_{50}$ values lower than $1 \mu \mathrm{mol} / \mathrm{L}$ and could be the primary contributors to fraction F4's ACE-inhibitory activity. ${ }^{39}$ The dipeptide VY showed a low $\mathrm{IC}_{50}$ value against $\mathrm{ACE}$ and behaved as a multifunctional bioactive peptide with antioxidant as well as DPP-IV and DPP-III inhibitory activities. ${ }^{40}$ Moreover, VY was found to be bioavailable in humans and effective in vivo, inducing a significant decrease in blood pressure in both highly and mildly hypertensive subjects with no observed changes in normotensive ones. ${ }^{41,42}$ In addition, other identified peptides with low or very low $\mathrm{IC}_{50}$ values (IVY, LVY, and LLF) have shown antihypertensive activity in vivo (in spontaneously hypertensive rats). ${ }^{35,43}$ According to studies of the structure-activity relationship, the presence of aromatic or hydrophobic amino acid residues (such as W, Y, F, I, L, and P) at the C-terminus and/or the amino acids G, I, L, $\mathrm{R}$, and $\mathrm{V}$ at the $\mathrm{N}$-terminus is pivotal for ACE inhibition. ${ }^{44}$ In this context, some peptides identified in fraction F4 (specifically, ISY, IGF, VSF, VTF, and VGL) might potentially inhibit the ACE activity. For example, the tripeptide ISY meets the structural requirement for ACE inhibition and shares the motif SY of the typical acknowledged ACE-inhibitory peptides such as SY, PSY, AHSY, LLPSY, and AKYSY ${ }^{45,46}$ Similarly, the tripeptides VSF and VTF are precursors of the ACE-inhibitory dipeptides SF and TF and share the C-terminal residues with other potent ACE-inhibitory peptides (such as FQPSF, EGGSF, LTF, and ITF). ${ }^{47,48}$ These peptides play a role in the ACE-inhibitory activity of F4 and can be further exploited for their potential inhibitory effect.

Additional peptides with other biological activities than antioxidant and ACE-inhibition were detected in fraction F4 and reported in Table S2. The asserted biological activities included dipeptidyl peptidase-IV (DPP-IV) and dipeptidyl peptidase-III (DPP-III) inhibitory activities, glucose uptake stimulating activity, renin inhibition, and immunostimulating activities. All of these identified bioactive peptides were short sequences of two or three amino acids. The majority of these peptides (37 identified peptides) showed a DPP-IV inhibitory activity. DPP-IV, a brush-border prolyl-dipeptidyl peptidase, is involved in the degradation of the insulinotropic hormones known as incretins. It is considered a molecular target for managing type 2 diabetes. ${ }^{49}$ It is known that DPP-IV inhibitory peptides are generally characterized by a hydrophobic feature. ${ }^{49}$ Accordingly, the presence of $\mathrm{Y}, \mathrm{L}, \mathrm{I}, \mathrm{V}, \mathrm{T}, \mathrm{G}$, and $A$ in the sequences of the identified di- and tripeptides listed in Table S2 likely boosted their efficacy, making them the main potential candidates as DPP-IV inhibitors.

In conclusion, this study highlights the potential use of $\mathrm{HPB}$ hydrolysate and fractions as multifunctional ingredients for the development of new healthy foods or for the pharmaceutical industry. Most of the bioactive peptides identified are short sequences of a few amino acids, potentially resistant to the gastrointestinal conditions. Indeed, some of these peptides have confirmed bioavailability in humans or rats. However, to validate the results, in vivo investigations are required to help us better understand the physiological significance of the alleged bioactivity. In the future, the production of hydrolysates enriched in bioactive peptides from the HPB protein extract may pave the way for new economic opportunities for this byproduct.

\section{ASSOCIATED CONTENT}

\section{Supporting Information}

The Supporting Information is available free of charge at https://pubs.acs.org/doi/10.1021/acs.jafc.1c01487.

List of the peptides identified in hemp bran Alcalase hydrolysate fraction F4 $(<1 \mathrm{kDa})$ (Table S1) and list of peptides and amino acids with previously described 
biological activity identified in the hemp bran Alcalase hydrolysate F4 (<1 kDa) (Table S2) (PDF)

\section{AUTHOR INFORMATION}

\section{Corresponding Author}

Elena Babini - Department of Agricultural and Food Sciences, Alma Mater Studiorum, University of Bologna, 47521 Cesena, Italy; CIRI (Interdepartmental Centre of Agri-Food Industrial Research), Alma Mater Studiorum, University of Bologna, 47521 Cesena, Italy; (1) orcid.org/0000-00019906-4909; Phone: +39 3405411068;

Email: elena.babini2@unibo.it; Fax: +390547 382348

\section{Authors}

Seyedeh P. Samaei - Department of Agricultural and Food Sciences, Alma Mater Studiorum, University of Bologna, 47521 Cesena, Italy

Serena Martini - Department of Life Sciences (DSV), University of Modena and Reggio Emilia, 42122 Reggio Emilia, Italy

Davide Tagliazucchi - Department of Life Sciences (DSV), University of Modena and Reggio Emilia, 42122 Reggio

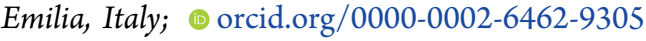

Andrea Gianotti - Department of Agricultural and Food Sciences, Alma Mater Studiorum, University of Bologna, 47521 Cesena, Italy; CIRI (Interdepartmental Centre of Agri-Food Industrial Research), Alma Mater Studiorum, University of Bologna, 47521 Cesena, Italy

Complete contact information is available at: https://pubs.acs.org/10.1021/acs.jafc.1c01487

\section{Author Contributions}

${ }^{\#}$ S.P.S. and S.M. contributed equally.

\section{Funding}

This research was supported by an Alma IDEA grant from Alma Mater Studiorum-University of Bologna. The authors acknowledge the Fondazione Cassa di Risparmio di Modena for funding the HPLC-ESI-Q Exactive Hybrid QuadrupoleOrbitrap Mass Spectrometer system at the Centro Interdipartimentale Grandi Strumenti (CIGS).

\section{Notes}

The authors declare no competing financial interest.

\section{ABBREVIATIONS}

ABTS, 2,2-azino-bis (3-ethylbenzothiazoline-6-sulfonic acid); ACE, angiotensin-converting enzyme; Alc, HPBPE hydrolysates with Alcalase; ARSA, ABTS radical scavenging activity assay; CVDs, cardiovascular diseases; DPPH, 2,2-diphenyl-1picrylhydrazyl; DRSA, DPPH radical scavenging activity assay; EDTA, ethylenediaminetetraacetic; FRAP, ferric-reducing antioxidant power assay; FCA, ferrous ion chelating activity assay; F1, Alc fraction with MW $>5 \mathrm{kDa} ; \mathbf{F} 2$, Alc fraction with MW between 5 and $3 \mathrm{kDa}$; F3, Alc fraction with MW between 3 and $1 \mathrm{kDa}$; F4, Alc fraction with $\mathrm{MW}<1 \mathrm{kDa}$; HPB, hemp bran; HPBPE, hemp bran protein extract; HPM, hemp meal; MW, molecular weight; SDS-PAGE, sodium dodecyl sulfatepolyacrylamide gel electrophoresis; TCA, trichloroacetic acid; TPTZ, 2,4,6-tri(2-pyridyl)-s-triazine

\section{REFERENCES}

(1) Lapeña, D.; Vuoristo, K. S.; Kosa, G.; Horn, S. J.; Eijsink, V. G. $\mathrm{H}$. Comparative assessment of enzymatic hydrolysis for valorization of different protein-rich industrial byproducts. J. Agric. Food Chem. 2018, 66, 9738-9749.

(2) Rizzello, C. G.; Tagliazucchi, D.; Babini, E.; Rutella, G. S.; Saa, D. L. T.; Gianotti, A. Bioactive peptides from vegetable food matrices: Research trends and novel biotechnologies for synthesis and recovery. J. Funct. Foods 2016, 27, 549-569.

(3) Toldrá, F.; Gallego, M.; Reig, M.; Aristoy, M. C.; Mora, L. Recent progress in enzymatic release of peptides in foods of animal origin and assessment of bioactivity. J. Agric. Food Chem. 2020, 68, $12842-12855$.

(4) Benjakul, S.; Morrissey, M. T. Protein hydrolysates from pacific whiting solid wastes. J. Agric. Food Chem. 1997, 45, 3423-3430.

(5) Jeon, Y.-I.; Byun, H.-G.; Kim, S.-K. Improvement of functional properties of cod frame protein hydrolysates using ultrafiltration membranes. Process Biochem. 1999, 35, 471-478.

(6) Klompong, V.; Benjakul, S.; Kantachote, D.; Shahidi, F. Antioxidative activity and functional properties of protein hydrolysate of yellow stripe trevally (Selaroides leptolepis) as influenced by the degree of hydrolysis and enzyme type. Food Chem. 2007, 102, 13171327.

(7) Tang, C. H.; Wang, X. S.; Yang, X. Q. Enzymatic hydrolysis of hemp (Cannabis sativa L.) protein isolate by various proteases and antioxidant properties of the resulting hydrolysates. Food Chem. 2009, $114,1484-1490$.

(8) Girgih, A. T.; Udenigwe, C. C.; Aluko, R. E. In vitro antioxidant properties of hemp seed (Cannabis sativa L.) protein hydrolysate fractions. J. Am. Oil Chem. Soc. 2011a, 88, 381-389.

(9) Girgih, A. T.; Udenigwe, C. C.; Li, H.; Adebiyi, A. P.; Aluko, R. E. Kinetics of enzyme inhibition and antihypertensive effects of hemp seed (Cannabis sativa L.) protein hydrolysates. J. Am. Oil Chem. Soc. 2011b, 88, 1767-1774.

(10) Girgih, A. T.; Udenigwe, C. C.; Aluko, R. E. Reverse-phase HPLC separation of hemp seed (Cannabis sativa L.) protein hydrolysate produced peptide fractions with enhanced antioxidant capacity. Plant Foods Hum. Nutr. 2013, 68, 39-46.

(11) He, R.; Girgih, A. T.; Malomo, S. A.; Ju, X.; Aluko, R. E. Antioxidant activities of enzymatic rapeseed protein hydrolysates and the membrane ultrafiltration fractions. J. Funct. Foods 2013, 5, 219227.

(12) O’Loughlin, I. B.; Kelly, P. M.; Murray, B. A.; FitzGerald, R. J.; Brodkorb, A. Molecular characterization of whey protein hydrolysate fractions with ferrous chelating and enhanced iron solubility capabilities. J. Agric. Food Chem. 2015, 63, 2708-2714.

(13) Olagunju, A. I.; Omoba, O. S.; Enujiugha, V. N.; Alashi, A. M.; Aluko, R. E. Pigeon pea enzymatic protein hydrolysates and ultrafiltration peptide fractions as potential sources of antioxidant peptides: An in vitro study. LWT-Food Sci. Technol. 2018, 97, 269278.

(14) Vollet Marson, G.; Belleville, M. P.; Lacour, S.; Dupas Hubinger, M. Membrane fractionation of protein hydrolysates from by-products: recovery of valuable compounds from spent yeasts. Membranes 2021, 11, 23.

(15) Wang, R.; Lu, X.; Sun, Q.; Gao, J.; Ma, L.; Huang, J. Novel ACE inhibitory peptides derived from simulated gastrointestinal digestion in vitro of sesame (Sesamum indicum L.) protein and molecular docking study. Int. J. Mol. Sci. 2020, 21, 1059.

(16) Nwachukwu, I. D.; Aluko, R. E. Structural and functional properties of food protein-derived antioxidant peptides. J. Food Biochem. 2019, 43, No. e12761.

(17) Aluko, R. E. Antihypertensive peptides from food proteins. Annu. Rev. Food Sci. Technol. 2015, 6, 235-262.

(18) Lu, R. R.; Qian, P.; Sun, Z.; Zhou, X. H.; Chen, T. P.; He, J. F.; Zhang, H.; Wu, J. Hempseed protein derived antioxidative peptides: Purification, identification and protection from hydrogen peroxideinduced apoptosis in PC12 cells. Food Chem. 2010, 123, 1210-1218.

(19) Girgih, A. T.; He, R.; Malomo, S.; Offengenden, M.; Wu, J.; Aluko, R. E. Structural and functional characterization of hemp seed (Cannabis Sativa L.) protein-derived antioxidant and antihypertensive peptides. J. Funct. Foods. 2014, 6, 384-394. 
(20) Das, R. Multienzyme modification of hemp protein for functional peptides synthesis. J. Food Process. 2015, 1, 738984.

(21) Malomo, S. A.; Onuh, J. O.; Girgih, A. T.; Aluko, R. E. Structural and antihypertensive properties of enzymatic hemp seed protein hydrolysates. Nutrients 2015, 7, 7616-7632.

(22) Aiello, G.; Lammi, C.; Boschin, G.; Zanoni, C.; Arnoldi, A. Exploration of potentially bioactive peptides generated from the enzymatic hydrolysis of hempseed proteins. J. Agric. Food Chem. 2017, 65, 10174-10184.

(23) Orio, L. P.; Boschin, G.; Recca, T.; Morelli, C. F.; Ragona, L.; Francescato, P.; Arnoldi, A.; Speranza, G. New ACE-Inhibitory peptides from hemp seed (Cannabis sativa L.) proteins. J. Agric. Food Chem. 2017, 65, 10482-10488.

(24) Pojić, M.; Mišan, A.; Sakač, M.; Dapčević Hadnađev, T.; Šarić, B.; Milovanović, I.; Hadnađev, M. Characterization of byproducts originating from hemp oil processing. J. Agric. Food Chem. 2014, 62, 12436-12442.

(25) Setti, L.; Samaei, S. P.; Maggiore, I.; Nissen, L.; Gianotti, A.; Babini, E. Comparing the effectiveness of three different biorefinery processes at recovering bioactive products from hemp (Cannabis sativa L.) byproduct. Food Bioprocess Technol. 2020, 13, 2156-2171.

(26) Hoyle, N. T.; Merritt, J. H. Quality of fish protein hydrolysates from herring (Clupea harengus). J. Food Sci. 1994, 59, 76-79.

(27) Benzie, I. F. F.; Strain, J. J. The ferric reducing ability of plasma as a measure of antioxidant power: the FRAP assay. Anal. Biochem. 1996, 239, 70-76.

(28) Sentandreu, M. A.; Toldra, F. A fluorescence-based protocol for quantifying angiotensin converting enzyme activity. Nat. Protoc. 2006, 1, 2423-2427.

(29) Martini, S.; Conte, A.; Tagliazucchi, D. Effect of ripening and in vitro digestion on the evolution and fate of bioactive peptides in Parmigiano Reggiano cheese. Int. Dairy J. 2020, 105, 104668.

(30) Minkiewicz, P.; Dziuba, J.; Iwaniak, A.; Dziuba, M.; Darewicz, $\mathrm{M}$. BIOPEP database and other programs for processing bioactive peptide sequences. J. AOAC Int. 2008, 91, 965-980.

(31) Qilin, L.; Zhang, C.; Chen, H.; Xue, J.; Guo, X.; Liang, M.; Chen, M. BioPepDB: an integrated data platform for food-derived bioactive peptides. Int. J. Food Sci. Nutr. 2018, 69, 963-968.

(32) Wang, X.; Tang, C.; Chen, L.; Yang, X. Characterization and antioxidant properties of hemp protein hydrolysates obtained with neutrase. Food Technol. Biotechnol. 2009, 47, 428-434.

(33) Hanafi, M. A.; Hashim, S. N.; Chay, S. Y.; Ebrahimpour, A.; Zarei, M.; Muhammad, K.; Abdul-Hamid, A.; Saari, N. High Angiotensin-I converting enzyme (ACE) inhibitory activity of Alcalase-digested green soybean (Glycine max) hydrolysates. Food Res. Int. 2018, 106, 589-597.

(34) Boschin, G.; Scigliuolo, G. M.; Resta, D.; Arnoldi, A. ACEinhibitory activity of enzymatic protein hydrolysates from lupine and other legumes. Food Chem. 2014, 145, 34-40.

(35) Martinéz-Maqueda, D.; Miralles, B.; Recio, I.; HernándezLedesma, B. Antihypertensive peptides from food proteins: a review. Food Funct. 2012, 3, 350-361.

(36) Martini, S.; Solieri, L.; Tagliazucchi, D. Peptidomics: new trends in food science. Curr. Opin. Food Sci. 2021, 39, 51-59.

(37) Sowmya, K.; Mala, D.; Bhat, M. I.; Kumar, N.; Bajaj, R. K.; Kapila, S.; Kapila, R. Bio-accessible milk casein derived tripeptide (LLY) mediates overlapping anti-inflammatory and anti-oxidative effects under cellular (Caco-2) and in vivo milieu. J. Nutr. Biochem. 2018, 62, 167-180.

(38) Babini, E.; Tagliazucchi, D.; Martini, S.; Dei Più, L.; Gianotti, A. LC-ESI-QTOF-MS identification of novel antioxidant peptides obtained by enzymatic and microbial hydrolysis of vegetable proteins. Food Chem. 2017, 228, 186-196.

(39) Wu, J.; Aluko, R. E.; Nakai, S. Structural requirements of Angiotensin I-converting enzyme inhibitory peptides: quantitative structure-activity relationship study of di- and tripeptides. J. Agric. Food Chem. 2006, 54, 732-738.
(40) Lan, V. T. T.; Ito, K.; Ohno, M.; Motoyama, T.; Ito, S.; Kawarsaaki, Y. Analyzing a dipeptide library to identify human dipeptidyl peptidase IV inhibitor. Food Chem. 2015, 175, 66-73.

(41) Matsui, T.; Tamaya, K.; Seki, E.; Osajima, K.; Matsumoto, K.; Kawasaki, T. Val-Tyr as a natural antihypertensive dipeptide can be absorbed into the human circulatory blood system. Clin. Exp. Pharmacol. Physiol. 2002, 29, 204-208.

(42) Kawasaki, T.; Seki, E.; Osajima, K.; Yoshida, M.; Asada, K.; Matsui, T.; Osajima, Y. Antihypertensive effect of valyl-tyrosine, a short chain peptide derived from sardine muscle hydrolysate, on mild hypertensive subjects. J. Hum. Hypertens. 2000, 14, 519-523.

(43) Nakano, D.; Ogura, K.; Miyakoshi, M.; Ishii, F.; Kawanishi, H.; Kurumazuka, D.; Kwak, C.; Ikemura, K.; Takaoka, M.; Moriguchi, S.; Iino, T.; Kusumoto, A.; Asami, S.; Shibata, H.; Kiso, Y.; Matsumura, Y. Antihypertensive effect of angiotensin I-converting enzyme inhibitory peptides from a sesame protein hydrolysate in spontaneously hypertensive rats. Biosci., Biotechnol., Biochem. 2006, 70, $1118-1126$

(44) Hyrinkiewicz, M.; Iwaniak, A.; Bucholska, J.; Minkiewicz, P.; Darewicz, M. Structure activity prediction of ACE inhibitory/bitter dipeptides-a chemometric approach based on stepwise regression. Molecules 2019, 24, 950.

(45) Balti, R.; Nedjar-Arroume, N.; Adje, E. Y.; Guillochon, D.; Nasri, M. Analysis of novel angiotensin I-converting enzyme inhibitory peptides from enzymatic hydrolysates of cuttlefish (Sepia officinalis) muscle proteins. J. Agric. Food Chem. 2010, 58, 38403846.

(46) Esteve, C.; Marina, M. L.; García, M. C. Novel strategy for the revalorization of olive (Olea europaea) residues based on the extraction of bioactive peptides. Food Chem. 2015, 167, 272-280.

(47) Suetsuna, K. Isolation and characterization of angiotensin Iconverting enzyme inhibitor dipeptides derived from Allium sativum $\mathrm{L}$ (garlic). J. Nutr. Biochem. 1998, 9, 415-419.

(48) Lassoued, I.; Mora, L.; Barkia, A.; Aristoy, M. C.; Nasri, M.; Toldrá, F. Angiotensin I-converting enzyme inhibitory peptides FQPSF and LKYPI identified in Bacillus subtilis A26 hydrolysate of thornback ray muscle. Int. J. Food Sci. Technol. 2016, 51, 1604-1609.

(49) Nongonierma, A. B.; Fitzgerald, R. J. Structure activity relationship modelling of milk protein-derived peptides with dipeptidyl peptidase IV (DPP-IV) inhibitory activity. Peptides 2016, $79,1-7$. 